\title{
Growth and regulation of enzyme synthesis in the nitrilotriacetic acid (NTA)-degrading bacterium Chelatobacter heintzii ATCC 29600
}

\author{
Matthias Bally, Elvira Wilberg, † Martin Kühni and Thomas Egli \\ Author for correspondence: Thomas Egli. Tel: +4118235158. Fax: +4118235547.
}

Swiss Federal Institute for Environmental Science and Technology (EAWAG) and Swiss Federal Institute of Technology (ETH), CH-8600 Dübendorf, Switzerland

\begin{abstract}
In the aerobic bacterium Chelatobacter heintzii, growth and regulation of enzymes involved in nitrilotriacetic acid (NTA) degradation have been investigated in chemostat culture during cultivation with glucose, NTA or mixtures thereof. In batch culture $\mu_{\max }$ with NTA was $0.18 \mathrm{~h}^{-1}$ and with glucose $0.22 \mathrm{~h}^{-1}$. Growth yields for both substrates were reduced at low dilution rates. During growth with NTA specific activity of the NTA monooxygenase (NTA-MO) exhibited a maximum at $D=0.03 \mathrm{~h}^{-1}$ and gradually decreased with increasing dilution rates. In glucose-grown cells the specific activity as well as immunologically detectable NTA-MO protein was always close to the detection limit. During cultivation with different mixtures of NTA and glucose at a dilution rate of $0.06 \mathrm{~h}^{-1}$, both substrates were utilized simultaneously, irrespective of the NTA/glucose ratio and the presence of excess ammonia. Synthesis of both NTA-MO and iminodiacetic acid dehydrogenase became induced when NTA contributed to more than approximately 1-3\% of the total carbon in the substrate mixture supplied. However, NTA was also degraded when the proportion of NTA in the mixture was lower than $1 \%$, which is consistent with the low constitutive level of expression for NTA-MO observed. Results are discussed with respect to NTA biodegradation during sewage treatment and in ecosystems.
\end{abstract}

Keywords: Chelatobacter beintzii, nitriloacetic acid monooxygenase, enzyme regulation, wastewater treatment, mixed substrate chemostat growth

\section{INTRODUCTION}

Nitrilotriacetate (NTA) is widely used as a complexing agent in both domestic and industrial cleaning agents but also in various other industrial applications including nuclear decontamination processes (Macaskie, 1991; Egli, 1988 ; McCrary \& Howard, 1979; Mottola, 1974). Due to the fact that NTA has been used to partially replace polyphosphates in laundry detergents this xenobiotic compound gave rise to considerable discussion because of its potential to remobilize heavy metals from polluted river sediments or soils. It was feared that accumulation of undegraded NTA could lead to heavy metal contami-

\footnotetext{
†Present address: Institute of Sanitary Engineering, Technical University
} of Aachen, D-52074 Aachen, Germany.

Abbreviations: DOC, dissolved organic carbon; DW, dry weight; IDA, iminodiacetic acid; IDA-DH, IDA dehydrogenase; NTA, nitrilotriacetic acid; NTA-DH, NTA dehydrogenase; NTA-MO, NTA monooxygenase. nation of drinking water supplies (Tiedje, 1980; Anderson et al., 1985).

In natural aquatic systems as well as in wastewater treatment plants the principal mechanism for the elimination of NTA is biodegradation. Several NTA-degrading strains have been isolated and characterized; most of them were found to be obligately aerobic Gramnegative rods or cocci (Wanner et al., 1990; Egli et al., 1988; Kakii et al., 1986; Cripps \& Noble, 1973; Enfors \& Molin, 1973a, b; Tiedje et al., 1973; Focht \& Joseph, 1971). Previously considered to be pseudomonads, the obligately aerobic strains have been shown to form two new genera, Chelatobacter and Chelatococcus, within the $\alpha$ subgroup of Proteobacteria (Auling et al., 1993), whereas the taxonomic position of the only well-characterized denitrifying strain is still uncertain (Wanner et al., 1990).

The biochemistry of NTA-degradation has been elucidated in obligately aerobic strains and in one denitrifying strain (Egli, 1994). In all obligate aerobes investigated so 
far the metabolism of NTA proceeds via a two-component monooxygenase (NTA-MO). The isolation of an enzyme catalysing the oxidation of NTA to glyoxylate and iminodiacetic acid (IDA) from Cb. heintzii ATCC 29600 has been recently reported (Uetz et al., 1992). In the same strain the presence of a membrane-bound IDA dehydrogenase (IDA-DH) responsible for the subsequent degradation of IDA to glycine and glyoxylate was detected (Uetz \& Egli, 1993). From the denitrifying strain TE 11 a NTA dehydrogenase (NTA-DH) able to catalyse the PMS-dependent oxidation of NTA to glyoxylate and IDA has been isolated and characterized (Jenal-Wanner \& Egli, 1993; Kemmler, 1993).

For both Chelatobacter and Chelatococcus strains it was found that ability to metabolize NTA was inducible (Egli, 1994; Uetz et al., 1992). However, it is presently not known how environmental conditions and nutritional status affect the regulation of both NTA-MO and IDA$\mathrm{DH}$ in these bacteria. Preliminary data suggested that the capacity to degrade NTA in the environment might be regulated via induction/repression rather than by enrichment of competent microbes (McFeters et al., 1990). Therefore, in $C b$. beintzii ATCC 29600 the influence of cultivation conditions on the expression of NTA-MO and IDA-DH was investigated in more detail in chemostat culture.

\section{METHODS}

Microbial strain and cultivation. Chelatobacter beintzii ATCC 29600 (Auling et al., 1993) was used in all experiments. The organism was pre-cultured in a synthetic medium described previously (Egli et al., 1988) with $2 \mathrm{~g} \mathrm{NTA}$ $\left(\mathrm{C}_{6} \mathrm{H}_{6} \mathrm{NO}_{6} \mathrm{Na}_{3} \cdot \mathrm{H}_{2} \mathrm{O}\right) 1^{-1}$ as the only source of carbon and nitrogen.

For continuous cultivation this medium was modified in the following way: $1.9 \mathrm{ml} \mathrm{H}_{3} \mathrm{PO}_{4}(85 \%$, w/w $) \mathrm{l}^{-1}$ was used in stead of sodium/potassium phosphate buffer, vitamins wert omitted, the concentrations of $\mathrm{MgSO}_{4} \cdot 7 \mathrm{H}_{2} \mathrm{O}$ and $\mathrm{CaCl}_{2} \cdot 2 \mathrm{H}_{2} \mathrm{O}$ were lowered to $0.3 \mathrm{~g} \mathrm{l}^{-1}$ and $0.02 \mathrm{~g} \mathrm{l}^{-1}$, respectively, and $10 \mathrm{mg}$ of silicone antifoam (Fluka) $\mathrm{l}^{-1}$ were added. The concentrations of carbon and nitrogen sources used varied between $0-4 \mathrm{~g}$ NTA $\mathrm{I}^{-1}, 0-2 \mathrm{~g}$ glucose (monohydrate) $\mathrm{l}^{-1}$ and $0-1.38 \mathrm{~g} \mathrm{NH}_{4} \mathrm{Cl} \mathrm{l}^{-1}$. The individual medium compositions used in the different experiments are given below. The bioreactor (MBR, Switzerland; 21 working volume) was aerated at a rate of 0.2 vol. vol. ${ }^{-1} \mathrm{~min}^{-1}$ (v.v.m.); $\mathrm{pH}$ was controlled at 6.8 with $\mathrm{H}_{3} \mathrm{PO}_{4}(1 \mathrm{M})$ and $\mathrm{KOH} / \mathrm{NaOH}(0.5 \mathrm{M}$ each). The temperature was maintained at $30^{\circ} \mathrm{C}$. Steady state conditions were defined as constant biomass concentration and NTA-MO activity. Each steady state data point represents the average of three independent samples.

\section{Measurement of enzyme activity}

Harvesting of cells and preparation of protein extracts. To prevent disturbance of established steady state conditions cells were harvested continuously from the chemostat outlet by immediately cooling down the culture liquid to $0^{\circ} \mathrm{C}$. Cells from $100 \mathrm{ml}$ portions were collected by centrifugation and were washed twice with Tris/HCl buffer $(30 \mathrm{mM}, \mathrm{pH} 8.0)$. The specific activity of NTA-MO was not affected by this procedure. Washed cells were resuspended in $1.8 \mathrm{ml}$ Tris $/ \mathrm{HCl}$ buffer $(30 \mathrm{mM}$, $\mathrm{pH} 8.0$ ), cooled in an ice/ethanol suspension and sonified
(Branson Sonifier 450 , duty cycle $30 \%$, output 3 ) six times for $1 \mathrm{~min}$ with a $30 \mathrm{~s}$ break between each cycle to ensure cooling. The resulting crude extract was centrifuged for $20 \mathrm{~min}$ at $30000 \mathrm{~g}$ to remove whole cells and debris. The supernatant was collected and centrifuged a second time for $60 \mathrm{~min}$ at $200000 \mathrm{~g}$. The resulting supernatant was tested for NTA-MO activity, whereas the pellet containing inner membrane fragments was used to assay for IDA-DH and succinate dehydrogenase activities.

NTA-MO activity. The assay was conducted according to the procedure described by Uetz et al. (1992) except that Tris $/ \mathrm{HCl}$ buffer $(30 \mathrm{mM}, \mathrm{pH} 8 \cdot 0), \mathrm{FMN}(10 \mu \mathrm{M})$ and $\mathrm{MgCl}_{2}(2 \mathrm{mM})$ were used. Each assay was performed in triplicate.

IDA-DH activity. The assay described by Uetz \& Egli (1993) was used to measure IDA-dependent oxygen consumption of inner membrane fractions. The pellet was rinsed with and then resuspended in Tris $/ \mathrm{H}_{2} \mathrm{SO}_{4}$ buffer $(30 \mathrm{mM}, \mathrm{pH} 8 \cdot 3)$. The suspended pellet $(0.5 \mathrm{ml})$ was added into a thermoregulated $\left(25^{\circ} \mathrm{C}\right.$ ) oxygen electrode cell (Rank Brothers) containing $1.7 \mathrm{ml}$ Tris $/ \mathrm{H}_{2} \mathrm{SO}_{4}$ buffer $(30 \mathrm{mM}, \mathrm{pH} 8 \cdot 3)$. Once the endogenous oxygen uptake rate was constant $0.3 \mathrm{ml}$ IDA (final concentration $30 \mathrm{mM}$ ) was added and the IDA-stimulated rate of oxygen consumption was determined.

\section{Immunoquantification of the two NTA-MO components}

Samples $(2 \mathrm{ml})$ of culture suspension were collected from the chemostat and cells were immediately harvested by centrifugation at $20000 \mathrm{~g}$ for $5 \mathrm{~min}$. The pellet was resuspended in $0.2 \mathrm{ml}$ of sample buffer (Laemmli, 1970), boiled for $3 \mathrm{~min}$, immediately frozen and stored at $-80^{\circ} \mathrm{C}$. For detection of NTA-MO components $\mathrm{A}$ and $\mathrm{B}$ the procedure described by Uetz et al. (1992) was followed. For quantification lysed cells in sample buffer were thawed and mildly sonified for $30 \mathrm{~s}$ and $10 \cdot 0 \mu \mathrm{l}$ of this suspension was loaded onto five different SDSpolyacrylamide gels. For calibration four standard concentrations of both component $\mathrm{A}(\mathrm{cA})$ and component $\mathrm{B}(\mathrm{cB})$ of NTA-MO were loaded onto each gel. The detection limits for $\mathrm{cA}$ and $\mathrm{cB}$ were about $0.3 \mathrm{ng}$ and $0.2 \mathrm{ng}$ protein, respectively.

Determination of NTA-dependent oxygen uptake rate of cells. A sample $(4 \mathrm{ml})$ of culture liquid was collected directly from the chemostat, washed once with and resuspended in the same volume of Tris/ $\mathrm{HCl}$ buffer $(50 \mathrm{mM}, \mathrm{pH} 7 \cdot 5)$ and the NTA-stimulated oxygen uptake rate was recorded at $25^{\circ} \mathrm{C}$ in a Clark-type oxygen probe (Rank Brothers). The total volume of the assay was $3.0 \mathrm{ml}$, consisting of $2.88 \mathrm{ml}$ of cell suspension of known optical density and $120 \mu \mathrm{l} \mathrm{NTA} / \mathrm{MgCl}_{2}(0 \cdot 1 \mathrm{M}$, each).

Biomass determination. Biomass was measured as dry weight by filtration through a $0 \cdot 2 \mu \mathrm{m}$ pore size polycarbonate membrane filter (Nuclepore). Cells collected on filters were washed with distilled water and filters were dried at $100^{\circ} \mathrm{C}$ to constant weight. Optical density was determined in a $1 \mathrm{~cm}$ cuvette at $546 \mathrm{~nm}$ with a Uvikon 860 spectrophotometer (Kontron).

\section{Analysis of substrate concentrations in the chemostat}

NTA. In NTA-MO assays the concentration of NTA was measured by high pressure ion exclusion chromatography (detection limit $1 \mathrm{mg} \mathrm{l}^{-1}$ ) as described by Schneider et al. (1988).

For measuring residual steady state concentrations of NTA in the chemostat culture $20 \mathrm{ml}$ of culture fluid were taken directly out of the bioreactor and cells were immediately separated from the culture medium by filtration through a $0 \cdot 2 \mu \mathrm{m}$ pore size polycarbonate membrane filter (Nuclepore). NTA concentrations in single substrate experiments were measured using the high pressure ion exclusion chromatography mentioned above. NTA concentrations in mixed substrate experiments were 
measured after derivatization by gas chromatography (Schaffner \& Giger, 1984). The detection limit was $200 \mathrm{ng} \mathrm{l}^{-1}$.

Glucose. Residual concentrations of glucose in the chemostat were analysed by HPLC according to Senn (1989).

Ammonia. The concentration of ammonia in filtered culture medium was measured using an automated nitrogen analyser (Breda Scientific) with a detection limit of $1 \mathrm{mg} \mathrm{NH}_{4}-\mathrm{N} \mathrm{l}^{-1}$.

Protein. The concentration of protein in cell-free extracts used for enzyme assays and in standard NTA-MO solutions used for quantification of components $A$ and $B$ was determined by the method of Bradford (1976). Bovine serum albumin (Fluka) was used as a standard.

\section{RESULTS}

\section{Growth and regulation of NTA-degrading enzymes in carbon-limited chemostat culture with a single substrate}

For $C b$. heintzii ATCC 29600 growth efficiency and the expression of the two key enzymes, NTA-MO and IDA$\mathrm{DH}$, were studied in carbon-limited chemostat culture during cultivation with either NTA or glucose/ammonia as the only sources of carbon and nitrogen.

Growth with NTA. The maximum specific growth rate, $\mu_{\max }$, observed in batch culture for growth with NTA as the only source of carbon and nitrogen (initial $\mathrm{Na}_{3} \mathrm{NTA} . \mathrm{H}_{2} \mathrm{O}$ concentration, $4 \mathrm{~g} \mathrm{l}^{-1}$ ) varied between $0 \cdot 17-0 \cdot 18 \mathrm{~h}^{-1}$ (Wilberg, 1989). However, in chemostat culture (concentration of $\mathrm{Na}_{3} \mathrm{NTA} . \mathrm{H}_{2} \mathrm{O}$ in feed, $4 \mathrm{~g} \mathrm{l}^{-1}$ ) cultivation at dilution rates higher than $0.15 \mathrm{~h}^{-1}$ was severely hampered by wall growth. The growth yield for NTA, $Y_{\mathrm{X} / \mathrm{NTA}}$, increased with increasing dilution rate and the highest yield of 0.24 was obtained at $D>0.11 \mathrm{~h}^{-1}$ (Fig. 1a). At growth rates below $0 \cdot 04 \mathrm{~h}^{-1}$ a marked decrease in yield was observed reaching approximately half of $Y_{\mathrm{X} / \mathrm{NTA} \text { (max) }}$ at $D=0.01 \mathrm{~h}^{-1}$. At all dilution rates tested the residual concentration of NTA was below the detection limit of the HPLC method used in this experiment $\left(1 \mathrm{mg} \mathrm{l}^{-1}\right)$. The specific consumption rate for NTA, $q_{\mathrm{NTA}}$, increased almost linearly with increasing growth rate. Extrapolation to zero growth rate demonstrated a maintenance coefficient of $0.02 \mathrm{~g} \mathrm{NTA}$ ( $\mathrm{g}$ DW $)^{-1} h^{-1}$ (Fig. 1a).

Growth with glucose/ammonium. In batch culture, growth with glucose and ammonia (initial concentrations of glucose. $\mathrm{H}_{2} \mathrm{O}$ and of $\mathrm{NH}_{4} \mathrm{Cl}, 2 \mathrm{~g} \mathrm{l}^{-1}$ and $1.38 \mathrm{~g} \mathrm{l}^{-1}$, respectively) as the only sources of carbon and nitrogen resulted in a $\mu_{\max }$ of $0 \cdot 21-0 \cdot 22 \mathrm{~h}^{-1}$ (Wilberg, 1989). In chemostat culture the maximum yield for glucose, $Y_{\mathbf{X} / \text { glucose(max) }}$, approached 0.43 at high growth rates, whereas a significant reduction of yield was observed at $D<0.02 \mathrm{~h}^{-1}$ (Fig. 1b). q glucose was found to increase linearly between $0 \cdot 02 \mathrm{~h}^{-1}<D<0 \cdot 17 \mathrm{~h}^{-1}$. Because wall growth was not apparent during growth with glucose, the notable decrease in growth yield at $D=0.01 \mathrm{~h}^{-1}$, and the resulting enhanced $q_{\text {glucose }}$, may result from a significantly increased maintenance coefficient. Extrapolation of the linear portion of the data set yields a maintenance coefficient of approximately 0.02 g glucose $(\mathrm{gDW})^{-1} \mathrm{~h}^{-1}$, which is in the same range as that found for
NTA. The maximum specific oxygen consumption rates $\left[q_{\mathrm{O}_{2}(\max )}\right]$ of chemostat-grown cells exposed in a Clarktype oxygen probe to excess concentrations of glucose or NTA are shown in Fig. 2. At low growth rates glucosestimulated $q_{\mathrm{O}_{2}(\max )}$ first increased with increasing dilution

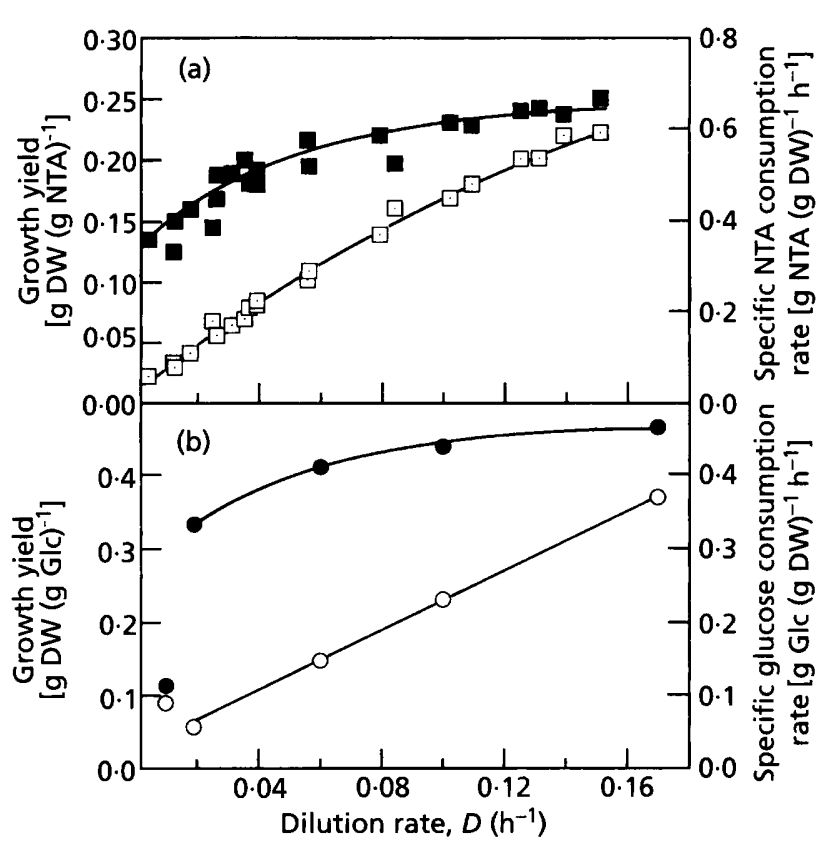

Fig. 1. Growth of $C b$. heintzii ATCC 29600 in carbon-limited chemostat culture with either glucose or NTA as a function of dilution rate. Growth yields and specific substrate consumption rates are shown. (a) Growth with NTA [substrate concentration in the feed $\left(S_{0}\right) 4 \mathrm{~g} \mathrm{Na}_{3} \mathrm{NTA} \mathrm{H}_{2} \mathrm{Ol}^{-1}$ ]: $\square$, growth yield; $\square$, specific NTA consumption rate. (b) Growth with glucose and ammonia [substrate concentrations in the feed $\left(S_{0}\right)$ were $2 \mathrm{~g}$ glucose $\mathrm{H}_{2} \mathrm{O}^{-1}$ and $1.38 \mathrm{~g} \mathrm{NH}_{4} \mathrm{Cl} \mathrm{I}^{-1}$ ]: $\bigcirc$, growth yield; $O$, specific NTA consumption rate.

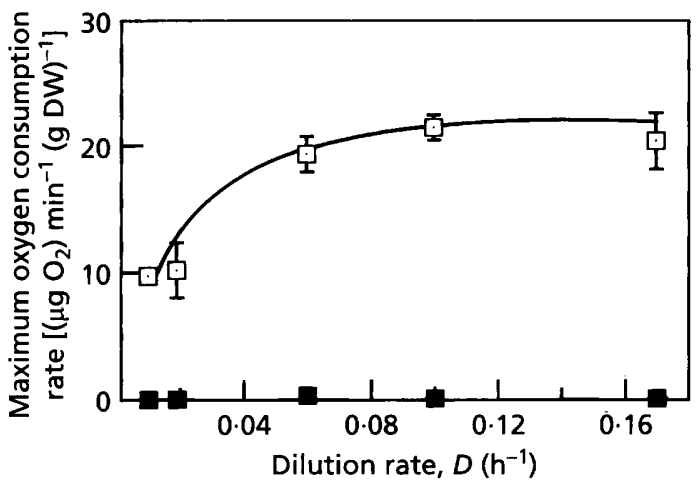

Fig. 2. Growth of $C b$. heintzii ATCC 29600 in carbon-limited chemostat culture with glucose as a function of dilution rate. Maximum specific oxygen consumption rates are shown [substrate concentrations in the feed $\left(\mathrm{S}_{0}\right)$ were $2 \mathrm{~g}$ glucose $\mathrm{H}_{2} \mathrm{O}$ $i^{-1}$ and $1.38 \mathrm{~g} \mathrm{NH}_{4} \mathrm{Cl}^{-1} \mathrm{l}: \square$, glucose-stimulated oxygen consumption rate; $\mathbf{D}$, NTA-stimulated oxygen consumption rate. 


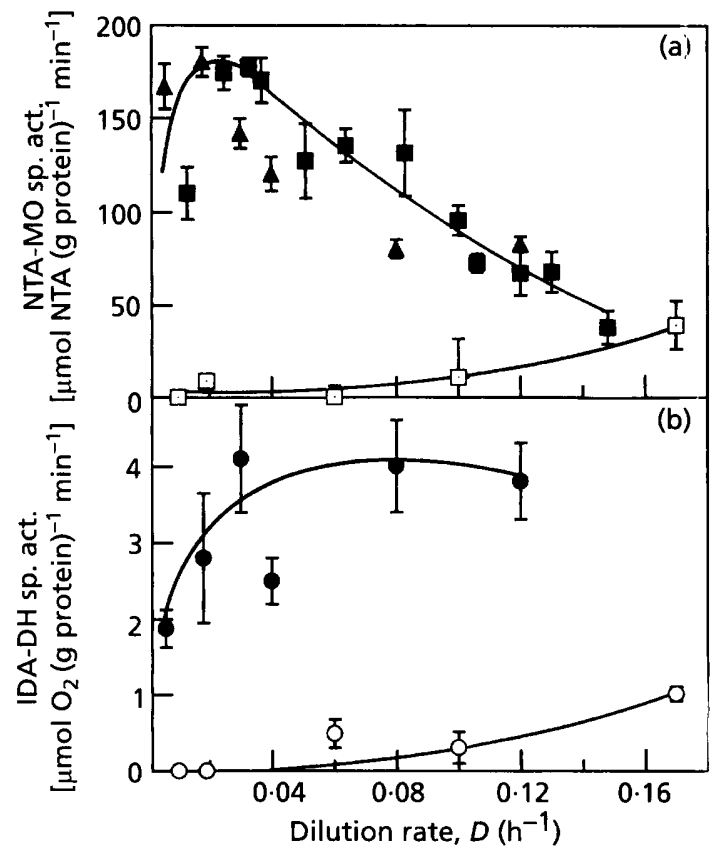

Fig. 3

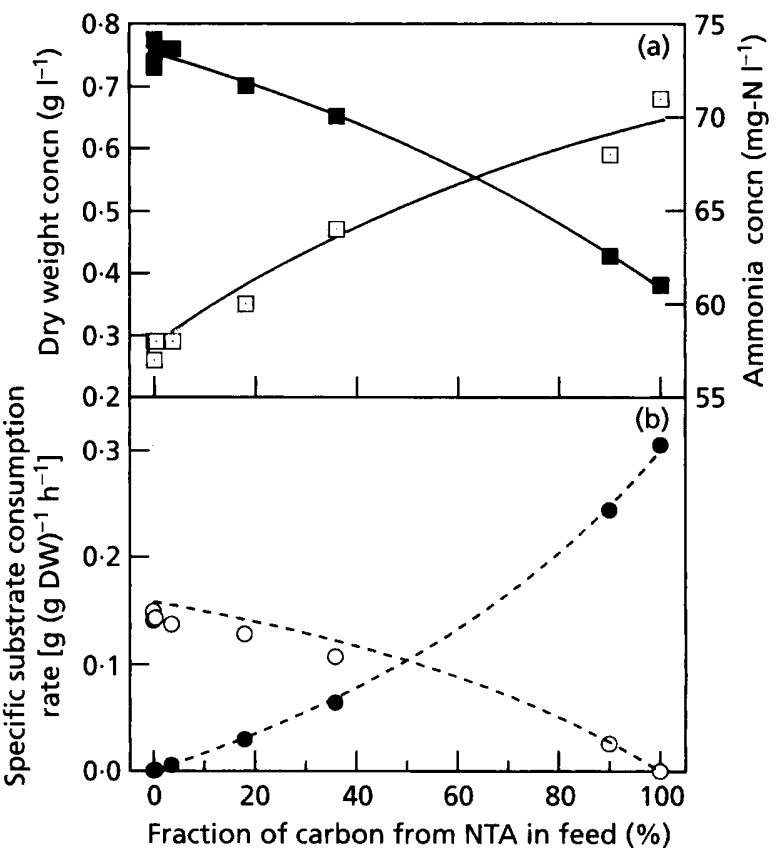

Fig. 4

Fig. 3. Growth of $\mathrm{Cb}$. heintzii ATCC 29600 in carbon-limited chemostat culture with either glucose or NTA as a function of dilution rate, illustrating regulation of enzymes involved in NTA metabolism. Substrate concentrations in the feed $\left(S_{0}\right)$ were either $4 \mathrm{~g} \mathrm{Na}_{3} \mathrm{NTA}_{2} \mathrm{H}_{2} \mathrm{Ol}^{-1}$, or $2 \mathrm{~g}$ glucose. $\mathrm{H}_{2} \mathrm{Ol}^{-1}$ and $1.38 \mathrm{~g} \mathrm{NH}_{4} \mathrm{Cl} \mathrm{l}^{-1}$. (a) Specific activity of NTA-MO:, growth on NTA, two different runs; $\square$, growth on glucose. (b) Specific activity of IDA dehydrogenase: growth on NTA; O, growth on glucose.

Fig. 4. Growth of $\mathrm{Cb}$. heintzii ATCC 29600 at a constant dilution rate of $D=0.06 \mathrm{~h}^{-1}$ in carbon-limited chemostat culture with mixtures of glucose plus NTA of different composition. The mixture composition supplied in the feed is given as the fraction of carbon from NTA in the feed. The concentration of total carbon in the feed was $60.6 \mathrm{mmol}^{-1}$. (a) $\square$, Dry weight; $\square$, ammonia concentration. (b) 0 , Specific NTA consumption rate, $q_{\text {NTA }} ; 0$, specific glucose consumption rate, $q_{\text {glucose. }}$ The dashed lines represent the theoretical predicted values of $q_{\text {NTA }}$ and $q_{\text {glucose }}$ calculated from equations (2) and (3) (see Discussion).

rates until it became constant at $D>0.08 \mathrm{~h}^{-1}$. At all dilution rates tested, the endogenous rate of oxygen consumption of glucose-grown cells was not detectably stimulated by NTA.

Regulation of enzymes involved in NTA degradation. During growth with NTA as the only carbon/nitrogen source the specific activity of NTA-MO increased with decreasing dilution rates (Fig. 3). The data, obtained from two independent experimental chemostat runs, indicate that NTA-MO specific activity exhibits a maximum at growth rates between $0.02-0.03 \mathrm{~h}^{-1}$. IDA-DH in NTAgrown cells was approximately constant at $D>0.03 \mathrm{~h}^{-1}$ but decreased considerably at lower growth rates (Fig. 3b).

During glucose-limited growth in chemostat culture the specific activity of NTA-MO was always close to the assay detection limit of $10 \mu \mathrm{mol}$ NTA (g protein) $)^{-1} \mathrm{~min}^{-1}$. Occasionally, low NTA-consuming activities were detected, e.g. at $D=0 \cdot 17 \mathrm{~h}^{-1}$, although at any dilution rate neither of the two NTA-MO components was immunologically detectable above the constitutive low level (data not shown). IDA-stimulated oxygen consumption of inner membrane fractions was detectable at $D>0.06 \mathrm{~h}^{-1}$
(Fig. 3b). Specific activity of IDA-DH at these growth rates was about $10 \%$ of the maximum specific activity found in NTA-grown cells.

\section{Growth in a carbon-limited chemostat with mixtures of NTA and glucose}

In both nature and wastewater treatment plants NTAdegrading micro-organisms will not only encounter NTA in their environment but they will grow in the presence of a complex mixture of potential carbon and/or nitrogen sources. It has been demonstrated previously that under laboratory batch conditions both Chelatobacter and Chelatococcus spp. are capable of utilizing NTA in combination with a suitable carbon substrate and that this usually results in enhanced growth rates (Egli et al., 1988). One can envisage that such mixed substrate growth should also occur under carbon-limited conditions in a chemostat and, consequently, one can assume that under environmental conditions also NTA-degraders will simultaneously utilize NTA in combination with other carbonaceous compounds. It has been shown earlier (Hamer et al., 1985; Uetz et al., 1992; Uetz \& Egli, 1993) and in the previous section that the synthesis of NTA-specific 


\section{Table 1. Growth of Cb. heintzii ATCC 29600 in carbon-limited chemostat culture}

$C b$. beintzii was grown at a constant dilution rate of $D=0.06 \mathrm{~h}^{-1}$ with mixtures of glucose + NTA of different composition. The mixture composition supplied in the feed is given as the fraction of carbon from NTA in the feed. The concentration of total carbon in the feed was $60.6 \mathrm{mmol}^{-1}$. NTA, glucose and ammonia concentrations in the feed $\left(S_{0}\right)$ and the corresponding steady state concentrations in the bioreactor $(S)$ are listed for each substrate mixture. The estimated maximum loss of residual substrate during the sampling procedure is indicated for the different mixtures. (All concentrations are $\mathrm{mg} \mathrm{l}^{-1}$.)

\begin{tabular}{|c|c|c|c|c|c|c|c|c|c|c|}
\hline $\begin{array}{l}\text { Substrate } \\
\text { composition }\end{array}$ & $\begin{array}{l}\% \text { NTA-C } \\
\% \text { Glucose-C }\end{array}$ & $\begin{array}{r}0 \\
100\end{array}$ & $\begin{array}{c}0.0004 \\
99.999\end{array}$ & $\begin{array}{l}0.036 \\
99 \cdot 96\end{array}$ & $\begin{array}{r}0.36 \\
99 \cdot 64\end{array}$ & $\begin{array}{r}3 \cdot 6 \\
96 \cdot 4\end{array}$ & $\begin{array}{l}18 \\
82\end{array}$ & $\begin{array}{l}36 \\
64\end{array}$ & $\begin{array}{l}90 \\
10\end{array}$ & $\begin{array}{r}100 \\
0\end{array}$ \\
\hline$S_{0}$ (NTA-C) & & - & 0.0026 & $0 \cdot 262$ & $2 \cdot 617$ & $26 \cdot 17$ & $130 \cdot 8$ & $261 \cdot 7$ & $654 \cdot 2$ & $727 \cdot 5$ \\
\hline$S$ (NTA-C) & & $0 \cdot 017$ & $0 \cdot 009$ & $0 \cdot 012$ & $0 \cdot 009$ & $0 \cdot 012$ & $0 \cdot 027$ & $0 \cdot 028$ & $0 \cdot 046$ & $0 \cdot 050$ \\
\hline $\begin{array}{l}\text { Estimated loss } \\
\text { of NTA-C }\end{array}$ & & $0 \cdot 000$ & $0 \cdot 000$ & $0 \cdot 000$ & $0 \cdot 001$ & 0.013 & $0 \cdot 065$ & $0 \cdot 131$ & $0 \cdot 327$ & $0 \cdot 364$ \\
\hline$S_{0}$ (glucose-C) & & $727 \cdot 3$ & $727 \cdot 2$ & $726 \cdot 9$ & $724 \cdot 4$ & $693 \cdot 1$ & $596 \cdot 4$ & $465 \cdot 8$ & $72 \cdot 7$ & - \\
\hline$S$ (glucose-C) & & $\sim 0.008$ & $\sim 0.008$ & $\sim 0.008$ & $\sim 0.008$ & $\sim 0.008$ & $\sim 0.008$ & $\sim 0.008$ & $\sim 0.008$ & $\sim 0.008$ \\
\hline $\begin{array}{l}\text { Estimated loss } \\
\text { of glucose-C }\end{array}$ & & $0 \cdot 048$ & $0 \cdot 048$ & $0 \cdot 048$ & $0 \cdot 048$ & 0.046 & $0 \cdot 040$ & $0 \cdot 031$ & $0 \cdot 005$ & $0 \cdot 000$ \\
\hline $\mathbf{N H}_{4}^{+}$in feed & & $464 \cdot 7$ & $464 \cdot 7$ & $464 \cdot 7$ & $464 \cdot 1$ & $458 \cdot 2$ & $432 \cdot 0$ & $399 \cdot 3$ & $301 \cdot 2$ & $282 \cdot 9$ \\
\hline Residual $\mathbf{N H}_{4}^{+}$ & & 73 & 74 & 74 & 74 & 75 & 77 & 82 & 87 & 91 \\
\hline
\end{tabular}

enzymes is repressed during growth with many carbon substrates. This raises the question to what extent NTAdegrading enzymes are expressed during simultaneous growth with mixtures of NTA plus additional carbon sources.

To investigate the regulation of NTA-MO and IDA-DH in $\mathrm{Cb}$. heintzii ATCC 29600 , cells were cultivated in carbon-limited chemostat culture at a constant dilution rate of $0.06 \mathrm{~h}^{-1}$ with different mixtures of glucose plus NTA supplied in the feed. In this experiment, the concentration of total carbon from either glucose and/or NTA in the medium feed was kept constant at $0.720 \mathrm{~g} \mathrm{l}^{-1}$. In addition, the medium always contained an excess concentration of nitrogen $\left(465 \mathrm{mg} \mathrm{l}^{-1}\right)$ either in the form of ammonia and/or of NTA.

Growth and substrate consumption rates. During growth with all mixtures tested NTA and glucose were used simultaneously down to concentrations of only a few $\mu \mathrm{g}^{-1}$ in spite of the presence of excess ammonium in the culture liquid (Table 1). Dry weight in the culture decreased linearly with increasing proportions of NTA in the mixture (Fig. 4a). This suggests that the growth yields for both substrates did not change as a function of the mixture composition supplied in the feed. As a consequence of the decrease of the combined growth yield, the concentration of residual ammonia increased almost linearly as the ratio of NTA/glucose was increased in the inflowing medium (Fig. 4a). The specific consumption rates for both glucose $\left(q_{\text {glucose }}\right)$ and NTA $\left(q_{\text {NTA }}\right)$ exhibited a slightly curved dependence on the ratio of the NTA/ glucose mixture fed (Fig. 4b).

The residual concentration of glucose was not influenced by the substrate mixture composition supplied and remained approximately constant at $8 \pm 3 \mu \mathrm{g}$ glucose- $\mathrm{C}$ $1^{-1}$ (Table 1). In contrast, the residual NTA concentration increased with increasing NTA proportions at NTA/ glucose ratios $>3.6 \%$, whereas during cultivation with NTA proportions lower than $3.6 \%$ the concentration of unutilized NTA was approximately constant in the range 9-17 $\mu \mathrm{g} \mathrm{NTA}-\mathrm{C}^{-1}$. It is noteworthy that NTA was also utilized simultaneously with glucose when it contributed only a minor fraction of the total carbon supplied in the feed, e.g. when a mixture consisting of $0.262 \mathrm{mg} \mathrm{NTA-C}$ $1^{-1}$ plus $726.9 \mathrm{mg}$ glucose- $\mathrm{Cl}^{-1}$ was supplied to the bioreactor the resulting NTA concentration in the culture

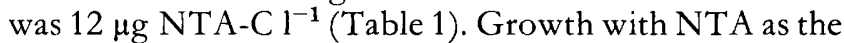
only carbon source resulted in a residual NTA concentration of about $50 \mu \mathrm{g} \mathrm{NTA}-\mathrm{Cl}^{-1}$. The measured concentrations of both NTA and glucose in Table 1 have to be interpreted with care because loss of substrate occurred during the sampling procedure. A worst-case estimate for the loss was made, assuming that the total time required for sampling was $30 \mathrm{~s}$ for NTA and $4 \mathrm{~s}$ for glucose and that consumption of the two substrates continued linearly at a rate identical to the specific consumption rate of the respective substrate. The values in Table 1 indicate that the measured residual concentrations of NTA might be significantly affected when taking into account the loss of substrate during sampling when the cells were cultivated with substrate mixtures containing $3.6 \%$ NTA-C or more. Similarly, one can expect that the residual glucose concentrations measured would also be affected during the sampling procedure when cells were grown with $10 \%$ or more glucose-C.

Regulation of enzyme activities. The specific activities of NTA-MO and IDA-DH together with the immunoquantification of the two NTA-MO components A and B are shown in Fig. $5(\mathrm{a}-\mathrm{c})$ as a function of the fraction of NTA-C supplied in the NTA/glucose mixture (note the logarithmic scale). Specific activities of both enzymes exhibited a similar regulation pattern. When NTA-C contributed less than approximately $1 \%$ of the total 


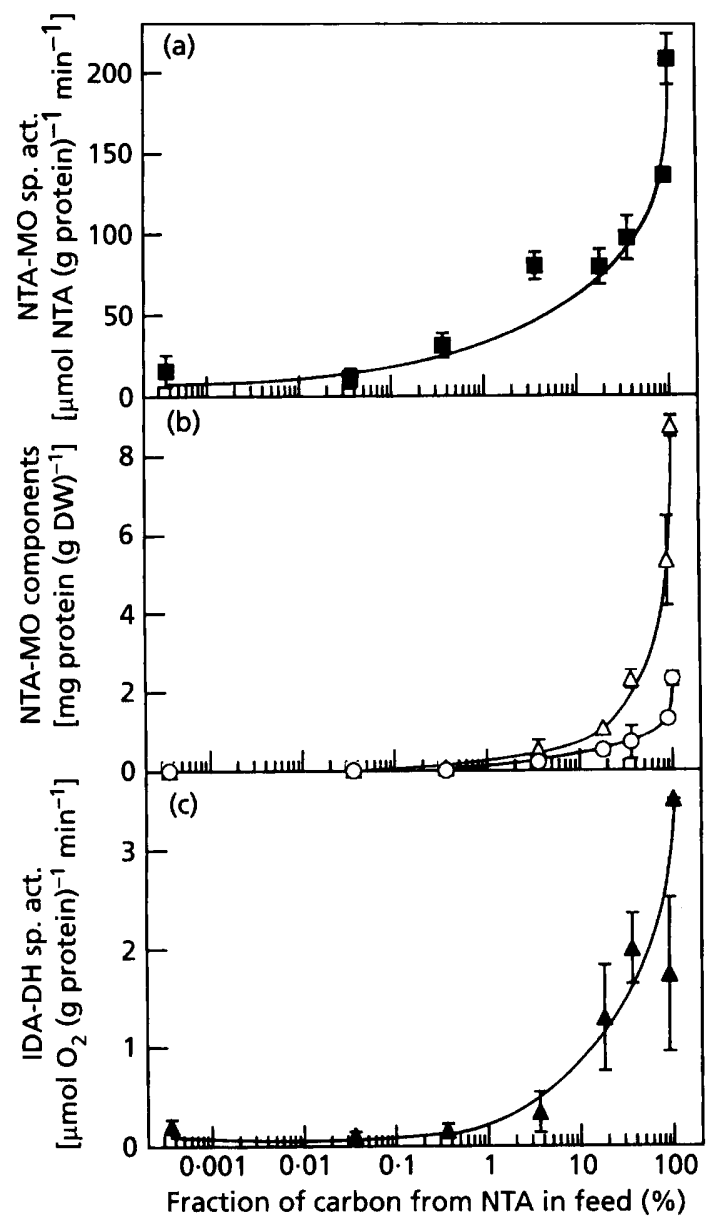

Fig. 5

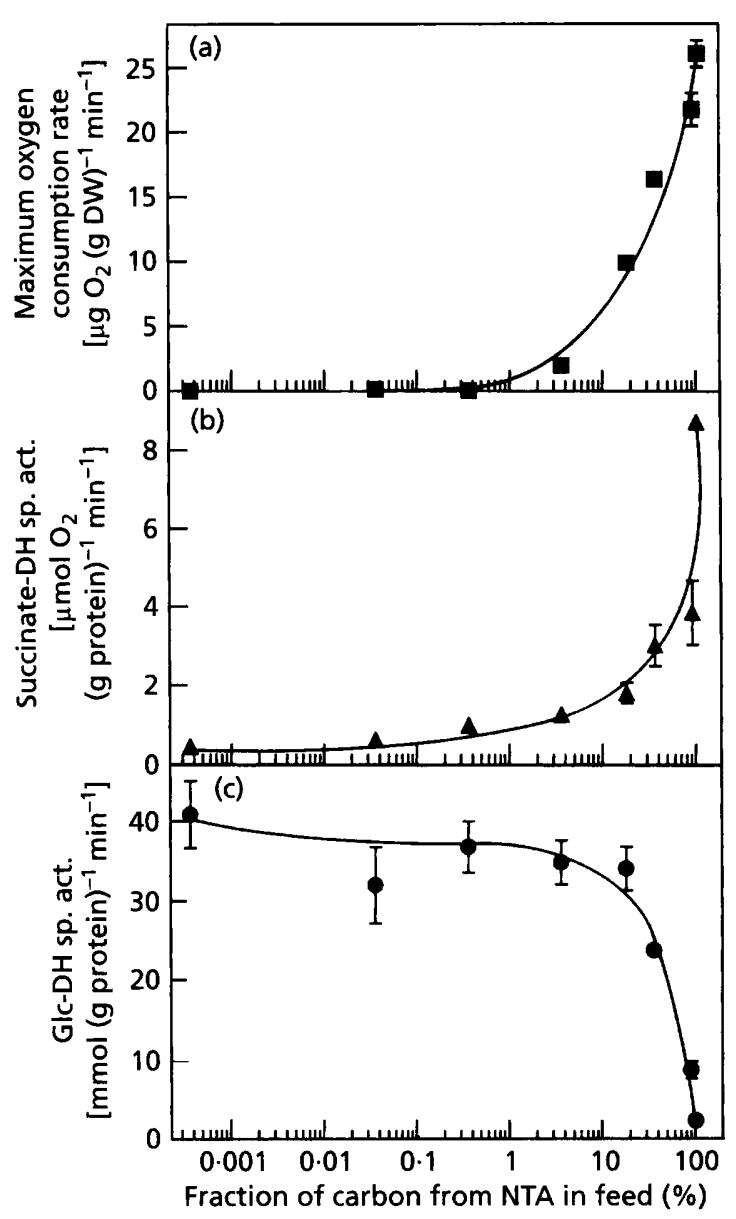

Fig. 6

Fig. 5. Growth of $C b$. heintzii ATCC 29600 at a constant dilution rate of $D=0.06 \mathrm{~h}^{-1}$ in carbon-limited chemostat culture with mixtures of glucose plus NTA of different composition, illustrating regulation of enzymes involved in NTA metabolism. The mixture composition supplied in the feed is given as the fraction of carbon from NTA in the feed. The concentration of total carbon in the feed was $60.6 \mathrm{mmol} \mathrm{I}^{-1}$. (a) Specific activity of NTA-MO; (b) immunological quantification of NTA-MO components $C A(\triangle)$ and $C B(O) ;(c)$ specific activity of IDA-DH.

Fig. 6. Growth of $\mathrm{Cb}$. heintzii ATCC 29600 at a constant dilution rate of $D=0.06 \mathrm{~h}^{-1}$ in carbon-limited chemostat culture with mixtures of glucose plus NTA of different composition. The mixture composition supplied in the feed is given as the fraction of carbon from NTA in the feed. The concentration of total carbon in the feed was $60.6 \mathrm{mmol}^{-1}$. (a) Regulation of specific NTA-stimulated maximum oxygen consumption rate; (b) specific succinate dehydrogenase activity; (c) specific glucose-6-phosphate dehydrogenase activity.

carbon consumed neither of the two enzymes were induced. However, compared to fully induced cells, background activities in the range $3-6 \%$ for NTA-MO and $2-3 \%$ for IDA-DH were always measured. The low constitutive expression of NTA-MO components A and $B$ was also detected immunologically. Clear induction of both enzymes was observed when the fraction of NTA-C contributed $3.6 \%$ or more of the total carbon supplied with the substrate mixture. Immunoquantification of the two components $\mathrm{A}$ and B of NTA-MO confirmed the pattern obtained for the specific activity of this enzyme. This strongly suggests that the increase in specific activity was due to enhanced expression of the two components of NTA-MO rather than to the modification of pre-existing NTA-MO components. Comparison of specific activity patterns for NTA-MO and IDA-DH with the specific
NTA consumption rate indicates that the degree of induction is not proportional to the flux of NTA through the pathway. Especially, induction of NTA-MO was more pronounced during growth with low ratios of NTA, whereas specific activity of IDA-DH reflected more closely the flux of NTA. NTA-stimulated maximum oxygen consumption rate followed the pattern exhibited by IDA-DH (Fig. 6a); however, in contrast to the low constitutive level of IDA-DH specific activity, no NTAstimulated oxygen consumption was detected during growth with low proportions of NTA. The specific activity of succinate dehydrogenase (Fig. 6b) displayed a similar pattern as that of IDA-DH, whereas the specific activity of glucose-6-phosphate dehydrogenase (Fig. 6c) reflected the flux of glucose through the cell (compare Fig. 4b) and decreased approximately linearly with 
decreasing $q_{\text {glucose }}$. The enhanced specific activity found for succinate dehydrogenase in NTA-grown cells confirms the theoretically expected increased flux of carbon through the TCA cycle during growth with NTA as compared to growth with glucose.

\section{DISCUSSION}

Biodegradation of pollutants in nature and wastewater treatment plants always takes place in the presence of complex mixtures of often easily degradable carbon and nitrogen substrates. In addition, nutrients are usually present at low concentrations and micro-organisms experience fluctuations with respect to environmental factors such as nutrient availability, hydraulic residence times or other physico-chemical parameters. One can envisage that in such systems one of the important parameters affecting the degradation of NTA by competent micro-organisms is the presence of other potential carbon/nitrogen substrates. The present investigation was focused on the influence of growth rate and the nature of the carbon/nitrogen substrates on the expression of enzymes involved in NTA metabolism in a NTAdegrading Chelatobacter strain during growth in continuous culture.

\section{Growth}

The low $Y_{X / \text { NTA }}$ of $0 \cdot 21$ measured at a growth rate of $0.06 \mathrm{~h}^{-1}$ in comparison to that for glucose $\left(Y_{X / \text { glucose }}=\right.$ 0.38 ) is consistent with the biochemical pathway as it was originally proposed for NTA by Cripps \& Noble (1973) and modified later (Egli, 1994). According to this pathway, assuming that assimilation of carbon into biomass takes place at the level of 2-phosphoglycerate, approximately $50 \%$ of the reducing equivalents (NADH) that can theoretically be produced from NTA in the initial metabolic pathway and subsequent oxidation in the tricarboxylic acid cycle have to be invested to transform NTA into a phosphorylated $\mathrm{C}_{3}$-metabolite.

The linear decrease of the biomass produced during growth with different mixtures of NTA plus glucose (Fig. 4a) indicates that formation of biomass from the two substrates occurred in an additive manner with constant growth yields according to equation (1). This is also visible from the hyperbolic pattern of the specific consumption rates for glucose and NTA in Fig. 4(b) which follows the theoretical predicted lines calculated from equations (2) and (3) employing values of 0.38 for $Y_{X / \text { glucose }}$ and 0.21 for $Y_{X / \mathrm{NTA}}$, measured at $D=0.06 \mathrm{~h}^{-1}$ during growth with single substrates (Fig. 1a, b). However, the final proof that the assimilation efficiency of the two substrates is not influenced by the mixture composition has to be confirmed, e.g. by using labelled substrates. The possibility remains that NTA is dissimilated preferentially to $\mathrm{CO}_{2}$ and the energy produced is used to assimilate more carbon from glucose. Both cases, i.e. additive and non-additive behaviour have been reported in the literature (Dijkhuizen \& Harder, 1979; Egli et al., 1982a; Müller et al., 1983).

$$
\begin{aligned}
& X_{\mathrm{tot}}=Y_{X / \mathrm{NTA}} \cdot\left(S_{0(\mathrm{NTA})}-s_{\mathrm{NTA}}\right)+Y_{X / \mathrm{glu}} \cdot\left(S_{0 \text { (glu })}-s_{\mathrm{glu}}\right) \\
& q_{\mathrm{NTA}}=\frac{D}{Y_{X / \mathrm{NTA}}+Y_{X / \mathrm{glu}}\left(\frac{S_{0(\mathrm{glu})}-s_{\mathrm{glu}}}{S_{0 \text { (NTA })}-s_{\mathrm{NTA}}}\right)} \\
& q_{\mathrm{glu}}=\frac{D}{Y_{X / \mathrm{glu}}+Y_{X / \mathrm{NTA}}\left(\frac{S_{0(\mathrm{NTA})}-s_{\mathrm{NTA}}}{S_{0(\mathrm{glu})}-s_{\mathrm{glu}}}\right)}
\end{aligned}
$$

In batch culture NTA-utilizing bacteria are known to use NTA in combination with a metabolizable carbon source when NTA is supplied as the only source of nitrogen (Hamer et al., 1985; Egli et al., 1988). However, it has never been tested whether under such conditions ammonia has the ability to repress the utilization of NTA. The experiments described here demonstrate that under carbon-limited chemostat conditions, $C b$. beintzii was able to simultaneously consume NTA together with glucose in spite of the presence of high ammonia concentrations. This is consistent with the fact that the utilization of NTA in these bacteria cannot be regulated by ammonia, since growth with NTA as the only source of carbon results in the intracellular production of ammonia and its subsequent excretion into the growth medium. It remains to be investigated whether or not other carbon/nitrogencontaining growth substrates, such as amino acids are able to repress the utilization of NTA.

The data in Table 1 suggest that the residual concentration of NTA increased with increasing proportions of NTA in the mixture, and vice versa for glucose. An estimate for the maximum loss of substrate due to the continued consumption of NTA or glucose during sampling can be made by assuming a linear consumption of substrate at the rate of $q_{\mathrm{s}}$ (compare Senn et al., 1994). It clearly shows that some of the measured values were strongly affected. This calculation indicates that the estimated true residual NTA and glucose concentrations as a function of the NTA/glucose-mixture composition will still increase with increasing proportions of NTA and glucose in the mixture, respectively. A similar pattern has been reported recently for the residual substrate concentrations for Escherichia coli growing at a constant dilution rate in the chemostat with differing mixtures of glucose plus galactose (Lendenmann et al., 1992; Egli et al., 1993).

The low residual NTA concentrations in the range 10-20 $\mu \mathrm{g}$ carbon $\mathrm{l}^{-1}$ from NTA detected in cultures containing only glucose as a carbon and energy source in the feed were found to originate from EDTA used for the preparation of the trace element solution (either from impurities or as a product of photodegradation). This was confirmed by the detection of NTA in the trace element stock solution.

\section{Regulation of enzymes}

Chemostat theory predicts that under ideal conditions residual substrate concentrations in a culture should be independent of culture density and this has been confirmed recently for growth with both single and mixed substrates (Rutgers et al., 1989; Senn et al., 1994). This 
implies that for growth with a particular ratio of NTA/glucose the residual concentrations of the two carbon sources should be independent of their concentrations in the inflowing medium. Therefore, residual substrate concentrations for NTA and glucose in the culture, as well as cellular composition and enzyme expression should depend on the ratio of the two substrates supplied in the feed only. To confirm this hypothesis $C b$. heintzii was also cultured with different mixtures of NTA plus glucose and the total carbon concentration in the feed was reduced to one-tenth of the original concentration. For all mixtures tested identical results were obtained for the specific activities of both NTA-MO and IDA-DH, as well as for the NTAstimulated oxygen consumption rate. Similarly, the combined growth yield from the two substrates remained constant. The observation that during mixed substrate growth the ratio of substrates - and not the actual concentrations in the feed-are controlling factors in enzyme regulation has also been reported for methylotrophic yeasts with mixtures of glucose and methanol (Egli et al., 1982a, 1983).

Repression of the synthesis of NTA-MO was found at high growth rates in NTA-limited chemostat culture. Similar patterns have also been observed for other catabolic enzymes in various microbes during growth under carbon limitation (Matin, 1979; van Dijken et al., 1976; Egli et al., 1982b; Tempest et al., 1983). The repression of the synthesis of NTA-MO observed at dilution rates higher than $0.03 \mathrm{~h}^{-1}$ might result from the fact that this enzyme contributes to a significant fraction of the cellular protein. Uetz et al. (1992) concluded that approximately $7 \%$ of the total protein was NTA-MO in cells grown at the maximum specific growth rate in batch culture. Since NTA-MO specific activity is proportional to the amount of NTA-MO proteins (Fig. 5a, b) the specific activity pattern shown in Fig. 3(a) suggests that at low growth rates approximately $20 \%$ of the intracellular protein consists of NTA-MO. Approximately equimolar concentrations of the two components $A$ and $B$ of NTAMO were reported for batch-grown cells of $C b$. beintzii (Uetz et al., 1992) whereas our results indicate a higher proportion of component A to be present. This might result from a partial degradation of the labile component $\mathrm{B}$ (Uetz et al., 1992) during cell breakage and sample handling.

The data indicate that in order to trigger induction of NTA enzymes above the constitutive background level [i.e. NTA-MO specific activities above $15 \mu \mathrm{mol}$ NTA (g protein $)^{-1} \mathrm{~min}^{-1}$, corresponding to $0.06 \mathrm{mg}$ NTA-MO protein $\left(\mathrm{g} \mathrm{DW}^{-1}\right.$ or more] a threshold flux of NTA, approximately $3 \%$ of the total carbon consumed, is required. At lower proportions of NTA the constitutive level of expression of NTA-MO and IDA-DH seemed to be sufficient for the breakdown of NTA present in the mixture. It is also possible that at low proportions of NTA, degradation proceeds by an additional, yet undetected, enzyme system.

The lack of expression of both NTA-MO and IDA-DH during growth with glucose can be explained either by repression by glucose or by the absence of an inducing effect of NTA. The experimental results, however, indicate that if expression is regulated by glucose, a flux of a few percent NTA relative to glucose can induce the system. The fact that expression of NTA-MO was not detected during starvation of the cells for carbon in the stationary phase of a complex medium batch culture (M. Bally \& T. Egli, unpublished) as well as during growth in glucose-limited chemostat culture at low growth rates indicates that derepression plays a minor role in the synthesis of this enzyme.

The medium used for cultivation of the cells contained EDTA. $\mathrm{Na}_{4}\left(\mathrm{H}_{2} \mathrm{O}\right)_{4}$ at a concentration of $26 \mathrm{mg} \mathrm{l}^{-1}$ originating from the trace element solution. Because the marked stimulation of expression of NTA-MO and IDADH started when the concentration of NTA in the medium was approximately equimolar to EDTA it is possible that EDTA might have influenced the pattern of expression of NTA enzymes via complexing a metal ion required for transport of NTA into the cell. Therefore, cells were cultivated with different mixtures of NTA plus glucose in which the concentration of EDTA in the medium was raised by a factor of ten. The fact that this changed neither the expression pattern for NTA-MO and IDA-DH nor the NTA-stimulated oxygen uptake rate confirmed that EDTA did not interfere with induction of NTA-specific enzymes.

\section{Ecological implications}

This study suggests that under environmental conditions NTA-degrading bacteria are able to utilize NTA not only simultaneously with glucose but probably also together with a range of other carbon substrates. With respect to the induction of NTA-degrading enzymes this raises the question as to what fraction NTA contributes to the total substrate utilized from the available carbon pool in the environment. Data available in the literature indicate that concentrations of NTA in river water are in the range $0 \cdot 4-4 \mu \mathrm{g}-\mathrm{C}^{-1}$. In rivers receiving a high load of treated sewage this concentration can increase to $8-16 \mu \mathrm{g}-\mathrm{Cl}^{-1}$ (Woodiwiss et al., 1979; Anderson et al., 1985; Houriet, 1990; Müller, 1986). Concentrations of dissolved organic carbon (DOC) in rivers and lakes are commonly in the range of a few $\mathrm{mg} \mathrm{l}^{-1}$ (Kaplan \& Newbold, 1993; Münster, 1993). Only a fraction of this DOC, usually some $1-5 \%$, is microbiologically available, indicating that most of the time heterotrophs are growing in such systems under carbon-limited conditions (Münster \& Chróst, 1990). Average concentrations of glucose, which often represents a significant part of the microbiologically utilizable organic carbon pool in surface waters, are typically in the range $5-20 \mu \mathrm{g}-\mathrm{C}^{-1}$ but can reach up to $100 \mu \mathrm{g}-\mathrm{Cl}^{-1}$ in trophogenic zones (Münster \& Chróst, 1990; Münster, 1993). This suggests that in rivers with high load of treated sewage NTA may contribute some $0 \cdot 1-1 \%$ of the total carbon. Considering glucose only, it would contribute some $10 \%$ of the utilizable carbon for these bacteria. Under the assumption that NTA-degrading enzymes are regulated via the flux of carbon from 
NTA contributing to the total carbon utilized one can speculate that - considering utilizable DOC - induction of NTA-specific enzymes should not be triggered, whereas if glucose was the primary carbon source for those bacte ria induction should play a role. Similarly, in the case of wastewater treatment plants the data available for DOC and NTA concentrations indicate that NTA might contribute some $1-10 \%$ of the total DOC; hence, induction of NTA-degrading enzymes can be expected to play a significant role under such conditions. Experiments performed by McFeters et al. (1989) with Cb. heintzii ATCC 29600 , where cells were pregrown in the laboratory under non-induced conditions, placed in membrane diffusion chambers and exposed in an aerated tank of a wastewater plant, confirmed the role of induction.

The data reported indicate that for a detailed understanding of the biodegradation of pollutants in nature during waste treatment it is important to consider the regulation of the enzymes involved and not only the enrichment of competent microbes. Unfortunately, little is available in the literature concerning the level of induction of pollutant-degrading enzyme systems (e.g. see Paul, 1993; Fleming et al., 1993).

\section{ACKNOWLEDGEMENTS}

The authors are indebted to A. J. Tien for correcting the English, G. Hamer for continuous support and T. Uetz for his help with the immunological enzyme quantification. M.B. acknowledges the hospitality in the groups of $\mathrm{E}$. Kellenberger and T. Bickle at the Biocenter of the University of Basel. We also thank H. U. Weilenmann for skilled technical assistance and F. G. Kari for the gas chromatographical determination of NTA at low concentrations. This research was supported from the Research Commission of ETH Zürich $(0.330 .089 .86 / 3)$ and also partially by a grant from Unilever and by EAWAG.

\section{REFERENCES}

Anderson, R. L., Bishop, W. E. \& Campbell, R. L. (1985). A review of the environmental and mammalian toxicology of nitrilotriacetic acid. CRC Crit Rev Toxicol 15, 1-102.

Auling, G., Busse, H. J., Egli, T., El-Banna, T. \& Stackebrandt, E. (1993). Description of the Gram-negative, obligately aerobic, nitrilotriacetate (NTA)-utilizing bacteria as Chelatobacter heintzii, gen. nov., sp. nov., and Chelatococcus asaccharovorans, gen. nov., sp. nov. Syst Appl Microbiol 16, 104-112.

Bradford, M. M. (1976). A rapid and sensitive method for the quantitation of microgram quantities of protein utilizing the principle of protein-dye binding. Anal Biochem 72, 248-254.

Cripps, R. E. \& Noble, A. S. (1973). The metabolism of nitrilotriacetate by a pseudomonad. Biochem J 136, 1059-1068.

van Dijken, J. P., Otto, R. \& Harder, W. (1976). Growth of Hansenula polymorpba in a methanol-limited chemostat. Arch Microbiol 111, 137-144.

Dijkhuizen, L. \& Harder, W. (1979). Regulation of autotrophic and heterotrophic metabolism in Pseudomonas oxalaticus OX1. Growth on mixtures of acetate and formate in continuous culture. Arch Microbiol 123, 47-53.

Egli, T. (1988). (An)aerobic breakdown of chelating agents used in household detergents. Microbiol Sci 5, 36-41.

Egli, T. (1994). Biochemistry and physiology of the degradation of nitrilotriacetic acid and other metal complexing agents. In Biochemistry of Microbial Degradation, pp. 179-195. Edited by C. Ratledge. Dordrecht: Kluwer Academic Publishers.

Egli, T., Käppeli, O. \& Fiechter, A. (1982a). Regulatory flexibility of methylotrophic yeasts in chemostat cultures: simultaneous assimilation of glucose and methanol at a fixed dilution rate. Arch Microbiol 131, 1-7.

Egli, T., Käppeli, O. \& Fiechter, A. (1982b). Mixed substrate growth of methylotrophic yeasts in chemostat culture: influence of the dilution rate on the utilisation of a mixture of glucose and methanol. Arch Microbiol 131, 8-13.

Egli, T., Lindley, N. D. \& Quayle, J. R. (1983). Regulation of enzyme synthesis and variation of residual methanol concentration during carbon-limited growth of Kloeckera sp. 2201 on mixtures of methanol and glucose. J Gen Microbiol 129, 1269-1281.

Egli, T., Weilenmann, H. U., El-Banna, T. \& Auling, G. (1988). Gram-negative, aerobic, nitrilotriacetate-utilizing bacteria from wastewater and soil. Syst Appl Microbiol 10, 297-305.

Egli, T., Lendenmann, U. \& Snozzi, M. (1993). Kinetics of microbial growth with mixtures of carbon sources. Antonie Leeuwenboek (Special Issue) 63, 243-274.

Enfors, S. O. \& Molin, N. (1973a). Biodegradation of nitrilotriacetate (NTA) by bacteria. I. Isolation of bacteria able to grow anaerobically with NTA as sole carbon source. Water Res 7, 881-888.

Enfors, S. O. \& Molin, N. (1973b). Biodegradation of nitrilotriacetate (NTA) by bacteria. II. Cultivation of an NTA-degrading bacterium in anaerobic medium. Water Res 7, 889-893.

Fleming, J. T., Sanseverino, J. \& Sayler, G. S. (1993). Quantitative relationship between naphthalene catabolic gene frequency and expression in predicting $\mathrm{PAH}$ degradation in soils at town gas manufacturing sites. Environ Sci \& Tecbnol 27, 1068-1074.

Focht, D. D. \& Joseph, H. A. (1971). Bacterial degradation of nitrilotriacetic acid. Can J Microbiol 17, 1553-1556.

Hamer, G., Egli, T. \& Mechsner, K. (1985). Biological treatment of industrial wastewater: a microbiological basis for process performance. J Appl Bacteriol, (Symposium Supplement) 127S-140S.

Houriet, J. P. (1990). Entwicklung der Konzentrationen des Waschmittelphosphatersatzstoffes "NTA" in den Gewässern, Situation 1990. BUW AL Bull 3, 28-39.

Jenal-Wanner, U. \& Egli, T. (1993). Anaerobic degradation of nitrilotriacetate in a denitrifying bacterium: purification and characterization of a NTA dehydrogenase/nitrate reductase enzyme complex. Appl Environ Microbiol 59, 3350-3359.

Kakii, K., Yamaguchi, H., Iguchi, Y., Teshima, M., Shirakashi, T. \& Kuriyama, M. (1986). Isolation and growth characteristics of nitrilotriacetate-degrading bacteria. J Ferment Technol 64, 103-108.

Kaplan, L. A. \& Newbold, J. D. (1993). Biogeochemistry of dissolved organic carbon entering streams. In Aquatic Microbiology, pp. 139-165. Edited by T. E. Ford. Boston: Blackwell.

Kemmler, J. (1993). Biochemistry of nitrilotriacetate degradation in the facultatively denitrifying bacterium TE 11. $\mathrm{PhD}$ thesis no. 9983, Swiss Federal Institute of Technology, Zürich, Switzerland.

Laemmli, U. K. (1970). Cleavage of structural proteins during the assembly of the head of bacteriophage T4. Nature 227, 680-685.

Lendenmann, U., Snozzi, M. \& Egli, T. (1992). Simultaneous utilisation of diauxic sugar mixtures by Escherichia coli. 6th International Symposium on Microbial Ecology (Barcelona, Spain), Abstracts, 254.

Macaskie, L. E. (1991). The application of biotechnology to the treatment of wastes produced from the nuclear fuel cycle: 
biodegradation and bioaccumulation as a means of treating radionuclide-containing streams. Crit Rev Biotecbnol 11, 41-112.

McCrary, A. L. \& Howard, W. L. (1979). Chelating agents. In KirkOthmer Encyclopaedia of Chemical Technology 5, 3rd edn, pp. 339-368. Edited by M. Grayson \& D. Eckroth. New York: Wiley.

McFeters, G. A., Egli, T., Wilberg, E., Alder, A., Schneider, R. P., Snozzi, M. \& Giger, W. (1990). Activity and adaptation of nitrilotriacetate (NTA)-degrading bacteria: field and laboratory studies. Water Res 24, 875-881.

Matin, A. (1979). Microbial regulatory mechanisms at low nutrient concentrations as studied in chemostat. In Strategies of Microbial Life in Extreme Environments, pp. 323-339. Edited by M. Shilo. Berlin Dahlem Konferenzen.

Mottola, H. A. (1974). Nitrilotriacetic acid as a chelating agent: applications, toxicology and bioenvironmental impact. Toxicol Environ Chem Rev 2, 99-161.

Müller, E. (1986). Entwicklung der NTA-Konzentrationen in den Schweizer Gewässern. BUS Bull 3, 4-9.

Müller, R., Markuske, K. D., Babel, W. (1983). Verbesserung der Y. Werte bei Wachstum von Hansenula polymorpba auf Methanol durch simultane Verwertung von Glucose. $Z$ Allg Mikrobiol 23, 375-384.

Münster, U. (1993). Concentration and fluxes of organic carbon substrates in the aquatic environment. Antonie Leeuwenboek (Special Issue) 63, 243-274.

Münster, U. \& Chróst, R. J. (1990). Origin, composition, and microbial utilization of dissolved organic matter. In Aquatic Microbial Ecology, Biochemical and Molecular Approaches, pp. 8-46. Edited by J. Overbeck \& R. J. Chróst. New York: Springer.

Paul, J. H. (1993). The advances and limitations of methodology. In Aquatic Microbiology, pp. 15-46. Edited by T. E. Ford. Boston: Blackwell.

Rutgers, M., Balk, P. A. \& van Dam, K. (1989). Effect of concentration of substrates and products on the growth of Klebsielia pneumoniae in chemostat culture. Biochim Biopbys Acta 977, 142-149.

Schaffner, C. \& Giger, W. (1984). Determination of nitrilotriacetic acid in water by high resolution gas chromatography. J Chromatogr 312, 413-421.

Schneider, R. P., Zürcher, F., Egli, T. \& Hamer, G. (1988).
Determination of nitrilotriacetate in biological matrices using ion exclusion chromatography. Anal Biochem 173, 278-284.

Senn, H. (1989). Kinetik und Regulation des Zuckerabbaus von Escherichia coli ML30 bei tiefen Zuckerkonzentrationen. $\mathrm{PhD}$ thesis no. 8831, Swiss Federal Institute of Technology, Zürich, Switzerland.

Senn, H., Lendenmann, U., Snozzi, M., Hamer, G. \& Egli, T. (1994). The growth of Escherichia coli in glucose-limited chemostat cultures: a reexamination of the kinetics. Biocbim Biopbys Acta (in press).

Tempest, D. W., Neijssel, O. M. \& Zevenboom, W. (1983). Properties and performance of microorganisms in laboratory culture; their relevance to growth in natural ecosystems. Symp Soc Gen Microbiol 34, 119-152.

Tiedje, J. M., Mason, B. B., Warren, C. B. \& Malec, E. J. (1973), Metabolism of nitrilotriacetate by cells of Pseudomonas species. Appl Microbiol 25, 811-818.

Tiedje, J. M. (1980). Nitrilotriacetate: hindsights and gunsights. In Biotransformation and Fate of Chemicals in the Aquatic Environment, pp. 114-119. Edited by A. W. Maki, K. L. Dixon \& J. Cairns, Jr. Washington, DC: American Society for Microbiology.

Uetz, T., Schneider, R., Snozzi, M. \& Egli, T. (1992). Purification and characterization of a two component monooxygenase that hydroxylates nitrilotriacetate from "Chelatobacter" strain ATCC 29600. J Bacteriol 174, 1179-1188.

Uetz, T. \& Egli, T. (1993). Characterization of an inducible, membrane-bound iminodiacetate dehydrogenase from Cbelatobacter beintzii ATCC 29600. Biodegradation 3, 423-434.

Wanner, U., Kemmler, J., Weilenmann, H. U., Egli, T., El-Banna, T. \& Auling, G. (1990). Isolation and growth of a bacterium able to degrade nitrilotriacetic acid under denitrifying conditions. Biodegradation 1, 31-42.

Wilberg, E. (1989). Zur Pbysiologie und Ökologie Nitrilotriacetat (NTA) abbauender Bakterien. PhD thesis no. 9015, Swiss Federal Institute of Technology, Zürich, Switzerland.

Woodiwiss, C. R., Walker, R. D. \& Brownridge, F. A. (1979). Concentration of nitrilotriacetate and certain metals in Canadian wastewaters and streams: 1971-1975. Water Res 13, 599-612.

Received 3 February 1994; revised 21 March 1994; accepted 31 March 1994. 